\title{
Determinants of Customer Complain intention: A Study from Pakistan
}

\author{
Muhammad Rizwan \\ Lecturer, Department of Management Sciences \\ The Islamia University of Bahawalpur, Pakistan \\ Email: rizwan.arshad@iub.edu.pk
}

Muhammad Behzad

Department of Management Sciences, The Islamia University of Bahawalpur, Pakistan

Muhammad Ali

Department of Management Sciences, The Islamia University of Bahawalpur, Pakistan

Muhammad Waqas Khan

Department of Management Sciences, The Islamia University of Bahawalpur, Pakistan

Moladad Khan

Department of Management Sciences, The Islamia University of Bahawalpur, Pakistan

DOI:10.5296/ ijld.v3i6.6207 URL: http://dx.doi.org/10.5296/ ijld.v3i6.6207

\begin{abstract}
Purpose: Objective of this study was to explore the impacts of prior experience and perceived controllability on attitude toward complains and loyalty, politeness, likelihood of success, and level of dissatisfaction on complain intention of Daewoo customer.

Scheme/method/style: Specially designed questionnaire was used for collection of data through convenience sampling Figures were composed through questionnaire, using expediency sample of 200 users from Bahawalpur.

Findings - Prior Experience and perceived controllability has a significant positive relationship with attitude toward complain. Attitude toward complain, politeness, loyalty, likelihood of success and Level of dissatisfaction keeps also significant positive relationship
\end{abstract}


with tendency toward complain.

Research boundaries/Consequences - Other sectors of service and manufacturing businesses except Daewoo can be considered in future to study the complain intention of customers. Moreover researchers can also work on other transportation businesses to find out the more determinants of complain intention of the customers.

Practical presumptions- According to this study, model of complaining intention can successfully be applied to the users of Daewoo.

Originality/value - numerous issues can be solved and steps can be taken for the betterment of service by understanding the complain intentions of consumers. This research finally facilitates the Daewoo management to satisfy their customers.

Keywords: Daewoo, complain intention, Pakistan

\section{Introduction}

Ideally when consumers in frustration speak up at once, firms avail the chance and take action instantaneously by improving their service quality. However, due to less complainants companies remain ignorant about the reasons of service failure. It is obvious that management failure does not necessarily mean to have a greater percentage of customer doubts to be delt with (Zairi, 2000), to a certain extent companies should support customers to convey whenever displeased (Barlow and Moller, 1996:26).

Complaints are usually considered as negative responses from discontented people and nearly all management tries to avoid and diminish them to the lowest level. But negative responses are considered as useful feedback in recent marketing studies and as "crucial markers of substandard routine" (Phau and Sari, 2004, p. 407).

Complaints have been found to facilitate companies to become conscious of troubles in services and are proficient to progress their presentation consequently. One can enhance customer dedication to the documents, establish consumer loyalty, and keep happy consumers by accepting consumer complaining activities and managing the objections efficiently (Oh, 2003, p. 60). There may be significant effect of complaint handling upon customer maintenance rates and word-of-mouth proposals. The majority of previous studies have paid attention on effective recovery tactics. However, a little research has been carried out to study the attitudinal and perceptual factors that have effect on consumer complaint intention. In dissatisfaction interrelated to services presented by firms, clients remain hushed when they turn to competitor corporations. They may even opt to the consumer's involvement when it becomes very much that cannot be taken and only a little fraction of clients prefer to describe frankly to the corporation about their unhappiness with regard to its services and request for progress (Tschlo, 1994).

Reasons behind customer loss of a unit can be taken as; product fault, the behavior of staff, dissatisfaction with pricing policies, other disquieting factors and the entity's insufficient 
policies regarding the complaint management. Therefore customer complaints should be considered as a tool to increasee the elements of marketing mix to render them likeliest with the target market rather regarding as a negative situation. In the sense of entities, the significance of customer complaints can be counted as below (Özkul and Bozkurt, 2006):

- About $14 \%$ of the existing customers don't sustain their relations with the entity because their complaints are not solved by the entity.

- About 9\% of the existing customers run off because of more attractive products of competing entities.

- About $15 \%$ and $\% 40$ of the customers, who report that they are satisfied with the offered products, require the products of other entities

- About 98 of the discontent customers never protest but switch to competing entities

- The cost of gaining a new customer is 5-8 fold more than retaining an existing customer

- The probability that "completely satisfied" customers will claim the products of an entity in 1 or 2 years is 6 fold than the probability that "satisfied customers" will acquire the products of an entity in one or two years.

Features of service providers' complaint-processing systems and evaluate customers' drive for complaint from the perspective of customer values has been discussed. Some researches also study diverse methods of complaining in an endeavor to observe the differentiation between alleged images of trademark, contentment, and re-purchase amongst clients who choose diverse complaining techniques. Studies linked with service collapse and improvement has focused on clients' behavior of complaining.

Our objective is to spotlight the complain intention of consumer and effect of some different variables on it. Among different variables abovementioned, differentiation of aspects that directs to singular ways of criticism is very important. In recent study an incorporated representation to comprehend the factors of consumers purpose to whine the companies and special belongings on grumbling aims.

Variables of this study are controllability, loyalty, prior experience, politeness, perceived likelihood of success, and level of dissatisfaction as independent variables where attitude towards complaint as mediator. Capability of corporations to envisage and avoid discontent shows controllability of dissatisfaction. Clients attitude towards complain will be more positive when they believe that problems are controlled by the firm. Complain intention can be enhanced by loyalty with the brand or company. If consumers are loyal with service or product provider they will make complaint to provider. Furthermore they have belongingness with brand. Prior complain experience affects attitude towards complaining. Positive politeness can express an admiration of the new person's whishes that will transmit a sagacity of correspondence and cohesion. There is a positive association between level of dissatisfaction and consumer intentions towards complain. The approach headed for a certain performance influences the goal to create such a comeback and the ultimate decision of 
acting or not. In the same way, a client's feelings in regard of complaining itself have an effect on the predisposition to criticize. This type of approach is called the individual confidence in the authenticity of a discontented client's taking reimbursement from the corporation (Richins, 1987).

\section{Literature Review}

This research builds up a structure to construe and foretell patrons inclination to make a complaint, as well as to converse interrelated variables. Consumer complaining behavior can be defined as "a set of several (Behavioral and non-behavioral) responses, some or all of which are elicited by perceived disappointment with a purchase episode" (Singh 1988). Consumer complaint intention can be examined as a result of consumer's attitudinal perspective rather than complain behavior, because intention is much better predicted and explained by attitude than is behavior (Fishbein and Ajzen, 1975; Ajzen and Fishbein, 1980). The central question in pre existing studies is that what will be the response of customer if not satisfied; what issues speckled which make options subjective; a special response is showed by which type of consumers; reason of complaint; what is the aim of complaining; contributing factors towards complaint and what will be the technique of managing complaint. Likelihood of discontented customer complaint is subject to propensity of making comlaint and related issues in the real-life milieu. Contextual issues comprise on time pressure and the accessibility of reference group's influence, While such inclination refers to subjective aim of the customer to initiate a complaint if not satisfied,. Provided that diverse situations are faced by consumers not satisfied, contextual issues have a major contribution to effects on different customers (Singh, 1989; Rizwan et al., 2013). At present real complaining behavior is of major concern. Complaint making through spotting factors that may influence complaint tendency can be explained and predicted by determinants in propensity and the underlying associations among attitude, intention and behavior. Hence test of determining factors of tendency to make complaint is the central focus of present study instead of the actual complaining behavior itself. In this study, consumers complain intention is dependent variable, which is defined as the plan of unhappy client to instigate a complaint to the firm. Complaining plan should rely on the five major variables related to attitudes and perceptions as recommended by anticipated model of recent study. The framework of model also depicts how attitudinal variable intervene the association between firm responses (controllability and prior complaint experience).

\subsection{Supposed controllability}

Supposed controllability is meant by how consumers think that whether the form has power over the problem or not. Ability of firms to foresee and put off frustration can be termed as controllability of dissatisfaction (chulmin kim, sounghie kim, subin im , chahoon shin 2003) Controllability is considered as the locus of duty for the discontent by various consumers affecting their attitude of making complaint and their behavior in response (Sing 1989).

\subsection{Prior Experiences}

Prior complaint experiences are considered as consumer's predisposition to demand when 
they are not satisfied (sing, 1989 and Wilkes, 1996). Prior complaint experiences affect attitude toward complaining. Customers develop more positive complaining attitude as they gain knowledge of the options, mechanism, and affirmative results of earlier complaining experiences (sing and wilkes, 1996).

\subsection{Attitude toward complaint}

Significance of attitude to complaining was explained by Hirschman (1970) in his theoretical framework for understanding complaint and exit behavior. Basic variable is attitude toward complaining that plays role in guessing the criticism behavior (Kim et al., 2003; Phau and Sari, 2004; Chebat et al., 2005; Bodey and Grace, 2006). Richins (1987) said that attitudes are subjective believes that are in tolerability of a dissatisfied customers ${ }^{\text {ee }}$ gaining return from the company. Along with the services firms also other business firms obtain and holding lucrative and loyal consumers by providing socks knocking atmosphere in the severe competition (Anderson and Zemke, 2007; Makens et al. 1999; Rizwan et al., 2013). Complaining and tending to hold a more positive attitude to achieve reimbursement is sagacious according to some thinkers while direct complaining is not favored by others.

\subsection{Loyalty}

About half of all clients stay dedicated to the service provider despite of not working out service problem (Levesque and McDougall, 2000). Because clients are ignorant of complaint procedure and they believe that no attention will be paid to their complaint therefore they choose to do nothing Such consumers think their complaint not able to produce encouraging result, or they may feel it expensive to make a complaint (Blodgett et al., 2006; Huppertz, 2007). Care about the relationship with the service provider is shown by Trustworthiness, a submissive response that ties member in a relationship with service (Hirschman, 1970; Naus et al., 2007; Mittal et al., 2008; Evanschitzky et al., 2011). Unhappiness due to some problem in service is shared by the faithful customer in the anticipation that things will get better in the upcoming times. Best customers can be retained with loyalty, a psychological obstacle, in spite of service failure (Panther and Farquhar, 2004; Naus et al., 2007).

\subsection{Politeness}

Goffman (1967) defines face as "the positive communal value a person effectively alleges for himself." The "kernel idea" of politeness theory is that "various acts are basically threatening to face and thus need 'softening", (Brown and Levinson, 1987, p. 24). According to Brown and Levinson (1987), a speaker may look for to keep up or augment the addressee's positive face and/or negative face. Meanwhile, the speaker would utilize "positive politeness" and "negative politeness" respectively. Positive politeness expresses an gratitude of the other person's wants and hence conveys a sense of similarity and solidarity. On the other hand, negative politeness is illustrated by self-effacement, ceremony, and control.

\subsection{Level of dissatisfaction}

Some researches sows the contribution of dissatisfaction to complaining behavior intentions (Mittal et al., 1999; Mittal and Kamakura, 2001; Oh, 2006). Past researches show 


\section{Macrothink}

International Journal of Learning \& Development

ISSN 2164-4063

2013, Vol. 3, No. 6

that the level of dissatisfaction has a positive relationship with consumer intentions towards change in behavior, negative word of mouth comments and complaining either to the service provider or to third parties. Previous literature conclude that the number of dissatisfied consumers who complain increases with the perceived importance of the situation, as does the number of consumers who leave the company when the complaint has not been solved (Levesque and MacDougall, 1996; Stephens and Gwinner, 1998; Oh, 2006).

\subsection{Perceived likelihood of success}

If there is services failure, some customer attribute some fault to themselves (Yuksel et al., 2006) predominantly in complex service situations (Harris et al., 2006; Anderson et al., 2009). Apparent probability of successful complaint is defined as the perceived probability of getting a reward such a refund, exchange, or apology through complaining to firm(Singh, 1990a). It is recognized that the chances of successful complaints positively affect complaint intention (Day and Landin, 1976;Rrchins, 1983b, 1985, 1987; Singh1990a,b). whilst consumer think that they are likely to express their complaining feelings to the firm. Conversely if they consider that the firm does not have any concern in their complaints, they will think that complaints will be worthless so they remain silent and never shop there another time.

Consequently, we hypothesize the following;

\section{Hypotheses and Research Model}

On the basis of above literature review, the current study tests the following hypotheses:

H1: The more prior experiences consumers have, the more positive attitude towards complaining.

$\mathrm{H}$ 2: Increased will be the complaining intention if higher is the perceived controllability the company has over the problem.

H3: A stronger inclination to instigate direct complaint will be observed if there is positive attitude toward complaining.

H4: Loyalty has negative effect on complain intention.

H5: Complaining behavior will decline as the propensity to be polite is raised.

H6: Complaint intention is increased by consumer's perceived likelihood of successful complaint.

H7: The level of dissatisfaction has positive effect on complain intention 
Figure 1: Hypothetical Model for the current research

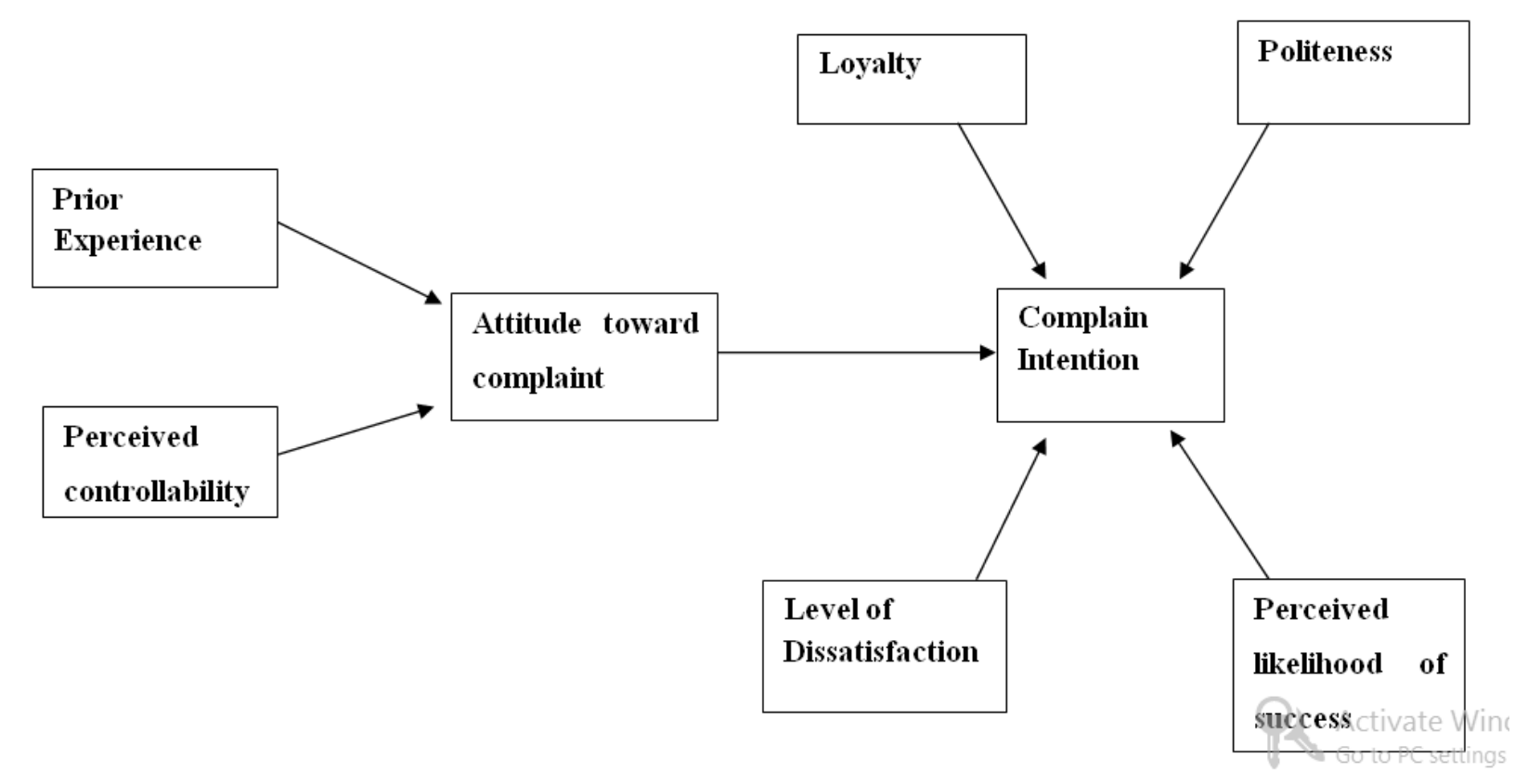

\section{Research Methodology}

Statistical nature of present study is descriptive which means to explain something or phenomenon by giving its description. Existing situations are described by descriptive researches instead of their interpretation (Creswell, 1994). Authentication of the established hypothesis reflecting the recent situation is the major objective of descriptive study. Information about the present circumstances are provided as well as present and past focused in this type of study. For instance, tourism industry and researchers currently are more engrossed in customer complaint behaviors which put forward chances for increasing customer satisfaction and profitability in developing customer management and marketing programs at enterprises /destinations (Rogers et al. 1992; Huang et al. 1996; Singh and Wilkes, 1996; Colgate and Norris, 2001).

\subsection{Sample/Data}

Questionnaires were provided to the Daewoo customer and they were asked for thinking that a situation relating a service failure that had happened to them. Previous researches helped in constructing survey questions. The target population of the study consists of students, employees, businessmen, unemployed and housewives who are Daewoo's customer. About 200 respondents participated in this study. The population for this research is customer of Daewoo bus service.

A well known sampling method was used in present study called as "convinience sampling". Convenience sampling is a sampling technique that acquires and gathers the relevant information from the sample or the unit of the study that are easily accessible (Zikmunt 1997). Convinience sampling is generally used for collecting a large number of complete surveys 
promptly in an economic way (Lym et al. 2010).

\subsection{Instrument and Measures}

The questionnaires were circulated among the disappointed passengers of Daewoo who had ever experienced service failure within 12 months. Participants were assisted and process was checked in order to achieve greater level of accuracy during the filling of questionnaires.

There were two types of questions; First type questions were designed to collect demographic data and basic information of customers. Second type questions were designed to measure research variables with 5-point Likert scale and designed as "strongly agree", "agree", "undecided", "disagree" and "strongly disagree".

Our variables of study are Attitude toward complain, Past experience, politeness, Complain intention, Brand loyalty, Controllability, Degree of dissatisfaction and likelihood of success with complain. The questionnaire has 7 items of Attitude toward complain, 3 items of Past experience, 6 items of Politeness, 3 items of complain intention, 7 items of Brand loyalty, 3 items of Controllability, 3 items of Degree of dissatisfaction and also 3 items of likelihood of success with complain.

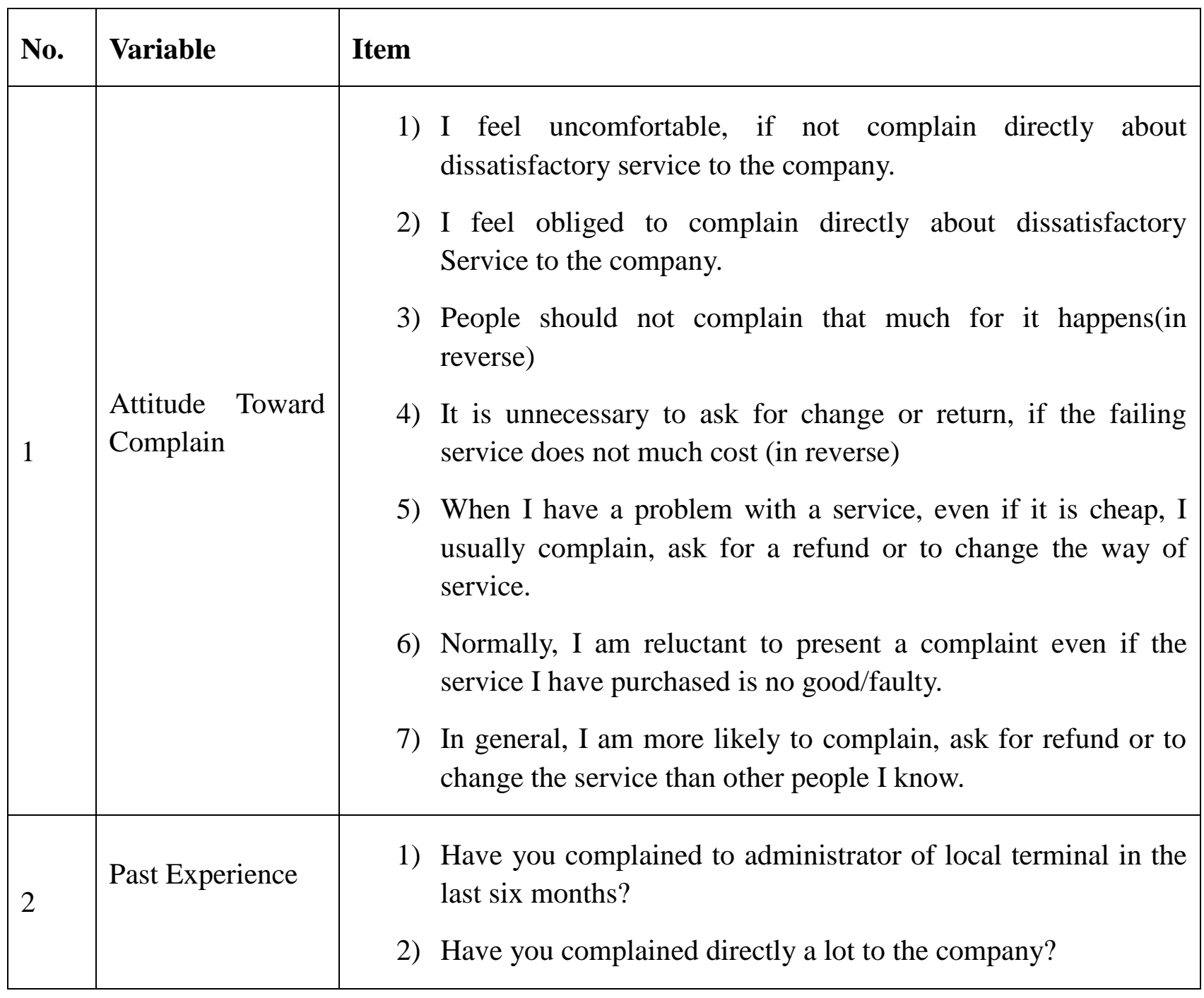




\begin{tabular}{|c|c|c|c|}
\hline & & 3) & $\begin{array}{l}\text { You have complained how many times directly to the company } \\
\text { so far }\end{array}$ \\
\hline 3 & Politeness & $\begin{array}{l}\text { 5) } \\
6)\end{array}$ & $\begin{array}{l}\text { When making a request, I am as direct as possible } \\
\text { It's OK for people to be forceful in order to get their way } \\
\text { I am comfortable asking people whom I barely know personal } \\
\text { question } \\
\text { I feel free to express my opinion when I disagree with } \\
\text { someone } \\
\text { I am forceful in order to get my way. } \\
\text { If asked whether or not I like something, I will frankly say if I } \\
\text { do not like it. }\end{array}$ \\
\hline 4 & $\begin{array}{l}\text { Complaint } \\
\text { Intention }\end{array}$ & $\begin{array}{l}\text { 2) } \\
\text { 3) }\end{array}$ & $\begin{array}{l}\text { I do not easily forget the unpleasant problems without } \\
\text { complaining or protesting. } \\
\text { I absolutely complain on site (or in the next visit) to the staff or } \\
\text { managers. } \\
\text { I absolutely ask for problems solving on site (or in the next } \\
\text { visit). }\end{array}$ \\
\hline 5 & Brand Loyalty & $\begin{array}{l}\text { 4) } \\
5) \\
6) \\
\text { 7) }\end{array}$ & $\begin{array}{l}\text { Daewoo would be my first choice. } \\
\text { I consider myself to be loyal to Daewoo. } \\
\text { I recommend Daewoo bus service to someone who seeks my } \\
\text { advice. } \\
\text { I get good value for my money. } \\
\text { I say positive things about this Daewoo to other people. } \\
\text { I am willing to pay premium price over competing services to } \\
\text { be able to purchase Daewoo service again. } \\
\text { I consider Daewoo my first choice in the next few years. }\end{array}$ \\
\hline 6 & Controllability & 2) & $\begin{array}{l}\text { The problem could have been prevented if I complain } \\
\text { It would not happen if the provider had been more precautious. } \\
\text { Strictly speaking, I was partly responsible. }\end{array}$ \\
\hline 7 & The degree of & 1) & How were you dissatisfied with the service quality? \\
\hline
\end{tabular}




\begin{tabular}{|l|l|l|l|}
\hline dissatisfaction & $\begin{array}{l}\text { 2) Were you dissatisfied with the service information? } \\
\text { 3) Overall, how dissatisfied were you with the service? }\end{array}$ \\
\hline 8 & $\begin{array}{l}\text { Likelihood of } \\
\text { success with the } \\
\text { complaint }\end{array}$ & $\begin{array}{l}\text { 1) How likely is it that the Daewoo terminal manager would take } \\
\text { the appropriate measures to solve the problem? }\end{array}$ \\
2) $\begin{array}{l}\text { How likely is that the Daewoo terminal manager would solve } \\
\text { the problem and offer you better service in the future? }\end{array}$ \\
3) $\begin{array}{l}\text { How likely is it that the Daewoo terminal manager would take } \\
\text { greater care in the future to ensure that customers are satisfied }\end{array}$ \\
\hline
\end{tabular}

\subsection{Procedure}

The questionnaire was distributed among 200 respondents on Daewoo terminal. These respondents were selected on the basis of criteria above mentioned. Before giving the questionnaire, the purpose of the study and questions were explained to the respondent so that they can easily fill the questionnaire with relevant responses. A total of 162 questionnaires were selected and rest of the questionnaires were not included in the further analysis due to invalid responses.

\section{Results and Analysis}

\section{Profile of the respondent}

Personal and demographic information such as gender, age, income, education level, status, frequency of Daewoo customer are presented in the following table (Table 1).

Table 1 The demographic Profile of Respondent

\begin{tabular}{|l|l|l|l|}
\hline Variables & Groups & Frequency & Percentage \\
\hline Gender & Male & 99 & 61.1 \\
& Female & 63 & 38.9 \\
\hline Age & $15-20$ years & 30 & 18.5 \\
$20-25$ years & 95 & 58.6 \\
$25-30$ Years & 27 & 16.7 \\
$30-35$ Years & 6 & 3.7 \\
$35-40$ years & 1 & .6 \\
\hline
\end{tabular}




\begin{tabular}{|c|c|c|c|}
\hline Income (Rs/month) & $\begin{array}{l}\text { below } 15000 \\
15000-25000 \\
25000-35000 \\
35000-45000 \\
45000-55000 \\
\text { Above } 50000\end{array}$ & $\begin{array}{l}101 \\
22 \\
8 \\
11 \\
12 \\
8\end{array}$ & $\begin{array}{l}62.3 \\
13.6 \\
4.9 \\
6.8 \\
7.4 \\
4.9\end{array}$ \\
\hline Education & $\begin{array}{l}\text { Matriculation } \\
\text { Inter } \\
\text { Bachelor } \\
\text { Master } \\
\text { MS /M. Phil } \\
\text { PHD }\end{array}$ & $\begin{array}{l}5 \\
11 \\
80 \\
37 \\
25 \\
4\end{array}$ & $\begin{array}{l}3.1 \\
6.8 \\
49.4 \\
22.8 \\
15.4 \\
2.5\end{array}$ \\
\hline Status & $\begin{array}{l}\text { Student } \\
\text { Employed } \\
\text { Businessman } \\
\text { Unemployed } \\
\text { Housewife }\end{array}$ & $\begin{array}{l}114 \\
38 \\
5 \\
1 \\
3\end{array}$ & $\begin{array}{l}70.4 \\
23.5 \\
3.1 \\
.6 \\
1.9\end{array}$ \\
\hline
\end{tabular}

\section{Reliability Analysis}

Overall Cronbach's alpha of Daewoo customers Complain Intention questionnaire items were 0.584 that is more than acceptable and recommended value 0.50 by Nunnally (1970). This shows that all the 35 items were reliable and valid to measure the opinion of consumers towards customer complaining behavior.

Table-2. Reliability of Measurement Instrument

\begin{tabular}{|l|l|l|}
\hline Variable & Items & Value \\
\hline Attitude towards complaint & 7 & 0.608 \\
\hline Prior experience & 3 & 0.821 \\
\hline Politeness & 6 & 0.674 \\
\hline
\end{tabular}




\begin{tabular}{|l|l|l|}
\hline Complaint intention & 3 & 0.503 \\
\hline Brand loyalty & 7 & 0.798 \\
\hline Controllability & 3 & 0.535 \\
\hline Degree of dissatisfaction & 3 & 0.759 \\
\hline Likelihood of success & 3 & 0.654 \\
\hline
\end{tabular}

\section{Hypothesis Testing}

\section{Prior Experience}

According to the result of the study, the variable of Prior Experience has a significant positive relationship with tendency to complain. Prior Experience of complain has a significant positive relationship with $(\beta=0.244)$ and $(p=0.002)$. This means the Prior Experience of complain contribute more than $24 \%$ to tendency to complain. Result of the current study validates $\mathrm{H} 1$

\section{Perceived Controllability}

According to the result of the study the variable of perceived controllability has a significant positive relationship with tendency to complain. Perceived Controllability of complain has a significantpositive relationship with $(\beta=0.146)$ and $(\mathrm{p}=0.062)$. This means that controllability of complain contributes more than $14 \%$ to tendency to complain. Result of the current study validates $\mathrm{H} 2$.

\section{Attitude toward complaint}

Theresults of study show that the variable of Attitude toward complaint has a significant positive relationship with tendency to complain. Attitude toward complaint of complain has a significant positive relationship with $(\beta=0.194)$ and $(\mathrm{p}=0.015)$. This means that the Attitude toward Complaint contribute more than $19 \%$ to tendency to complain. Result of the current study validates $\mathrm{H} 3$.

\section{Loyalty}

According to the result of the study the variable of Loyalty has a significant positive relationship with tendency to complain. Loyalty has positive relationship with $(\beta=0.004)$ and $(\mathrm{p}=0.964)$. This means that the variable of Loyalty contribute more than $.4 \%$ to tendency to complain. Result of the current study validates H4. 


\section{Macrothink}

\section{Politeness}

According to the result of the study the variable of Politeness has a significant positive relationship with tendency to complain Politeness has positive relationship with $(\beta=0.148)$ and $(\mathrm{p}=0.063)$. This means that the variable of Politenesscontribute more than $14 \%$ to tendency to complain. Result of the current study validates H5.

\section{Degree of Dissatisfaction}

According to the result of the study the variable of Degree of Dissatisfaction has a significant positive relationship with tendency to complain. Degree of Dissatisfaction has positive relationship with $(\beta=0.060)$ and $(p=0.447)$. This means that the variable of Degree of Dissatisfaction contribute more than $6 \%$ to tendency to complain. Result of the current study validates $\mathrm{H} 6$.

\section{Perceived likelihood of success}

According to the result of the study the variable of perceived likelihood of success has a significant positive relationship with tendency to complain. perceived likelihood of success has positive relationship with $(\beta=0.179)$ and $(\mathrm{p}=0.039)$. This means that the variable of perceived likelihood of success contribute more than $18 \%$ to tendency to complain. Result of the current study validates $\mathrm{H} 7$.

H4

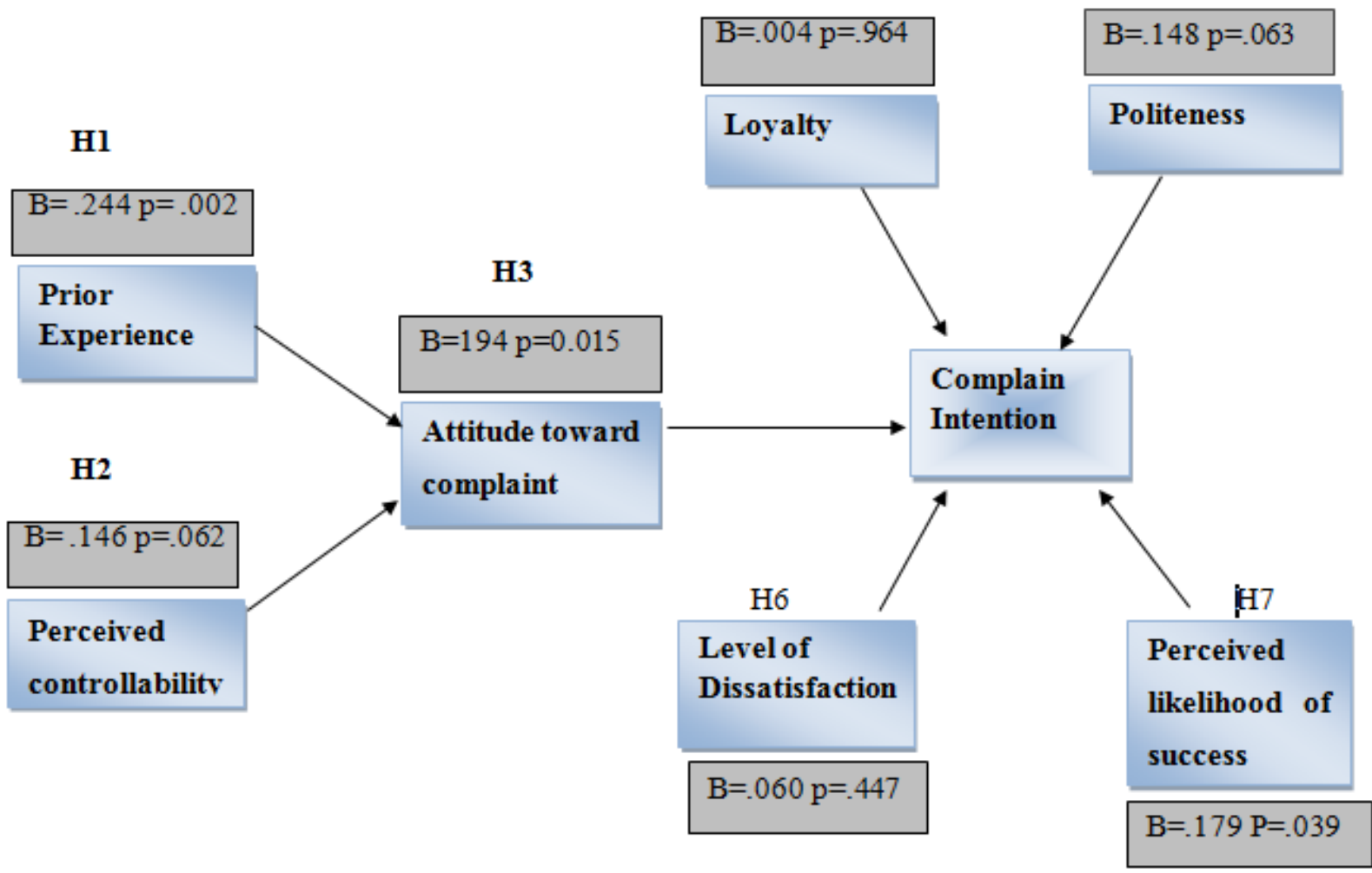

Figure 2: Structural Model Results 


\section{Discussion}

The main objective of the study is to examine the variables effecting consumers complaining behavior. During the study we found out that all variables have positive relationship with the complaining behavior of Daewoo customers. Research prove that prior experiences and perceived controllability have a positive effect on the attitude towards complaining, which further effects the complaining intention. When the customers are dissatisfied from a product or service they either complaint to the service provider or keep silent, both consumer responses are affected by controllability and prior experiences, if consumers have prior compliant experiences and have the perception that the company has control over the problem than they will directly complaint against their dissatisfaction of the service failure. The attribution of failure in a product or service will affect the customer's response in that one's intension to make direct complaint and ask for problem solving will be intensified when the cause of the problem is defined as factors that could be prevented or controlled by the company (folks 1989). Research finds out that if company has power over the situation and consumer also have prior experiences of complaining than they have a more positive attitude towards complaining.

Based on an empirically tested testimony, Singh (1988) introduced three types of complaining behaviors: voice, third party action, and private actions. For the most part, voice refers to complaining behavior directed toward the offending confronting or publically humiliating the service provider. It is expected that the consumers will take private actions independent of the propensity to be polite. Additionally consumer politeness has been claimed for having negative effects on the compliant intention but the scenario in the Daewoo bus service users seems to be different, our study finds out that the more polite the consumers have more positive attitude towards complaining. Secondly we have discussed consumer loyalty, level of dissatisfaction and perceived likelihood of success having positive affects over complaining behavior. In the prior researches it was observed that consumer loyalty has negative impacts over the attitude toward complaining as Levesque and McDougall (2000) suggested that half of all consumers would remain loyal to the service provider even when a service failure is not solved but our study has a another side of the picture where it suggests that the consumer loyalty plays a positive role in the complaining intention and severe service failure leads the consumers to abandon the service provider and switch to other service provider moreover we observed that consumer loyalty depends upon the feedback of the firm regarding complaints against the service failure.

Level of dissatisfaction builds a positive attitude towards complaining, complaining intention will differ with severity of the dissatisfaction. Highly dissatisfied costumers poses extreme intention to complaint against the service failure while less dissatisfied customers have low intentions to complaint against their dissatisfaction regarding service failure moreover less dissatisfied customers keep silent regarding the service failure and switch to other rival companies silently and spreading negative word of mouth against the firm to their chums. $(\mathrm{Li}$ Yin Jin,2009). As (PiotrChelminski and robin A.Coulter ,2011) argue that severe service failure lead to negative word of mouth rather than voicing whereas negative word of mouth proves to be more dangerous for the firm and builds a negative image of the firm in the 
marketplace. Moreover our study finds out that consumers having higher perception of a successful complaint have more positive attitude towards complaining. Consumers usually don't complaint against the service failure if they don't perceive any positive feedback from the firm such as refunding or repair of the loss incurred because of the failed services offered by the firm. Previous researches also argue that the greater the perceived possibility of successful compliant making, the greater the intention is for the customer to complain directly to company (Sing, 1989; Richins, 1987). Usually customers don't complaint against service failure if they don't perceive any positive feedback from the company while prior experiences of making complaints build up the intention for the complaint making attitude. Some researchers believe a company's response to an attitude towards such issue will influence possibilities of customer's compliant making (Day and Landon,1977). Sometimes consumers are discouraged from speaking up by

negative complaint handling procedures, such as simple apologies and nothing more, rejection

(verbal or non verbal), promises that are not acted upon, no response at all, rude treatment, being

passed on to someone else, employees who avoiding personal responsibility or consumer interviews that turn into interrogations (Barlow and Moller, 1996:59-61).

\section{Limitations}

The study's limitations are that it is directed in a small metropolis of Bahawalpur, which is able to differ in other cities. Thus the inference has to be more inspected by readings of alternative cities to check if it works. Future research can be conducted to find out complain intention of customers other than the Daewoo users. Further research can be conducted in other transport companies operating in Pakistan i.e. Faisal movers, Niazi Express, Power international etc. There are lot of other sectors (like pharmaceutical, fastfood restaurants, Leasing companies etc.) on which research can be conducted to check out the factors of complain intentions. Research scholars can also focus on additional factors which can affect the complain intention of Daewoo users.

\section{References}

- Anderson, S.W., Baggett, L.S. and Widener, S.K. (2009), "The impact of service operations failures on customer satisfaction: evidence on how failures and their source affect what matters to customers", Manufacturing and Service Operations Management, Vol. 11 No. 1, pp. 52-69

- Bodey, K. and Grace, D. (2006), "Segmenting service 'complainers' and 'non-complainers' on the basis of consumer characteristics", The Journal of Services Marketing, Vol. 20 No. 3, p. 178

- Brown, P. and Levinson, S.C. (1987), Politeness: Some Universals in Language Usage, 


\section{Macrothink}

International Journal of Learning \& Development

ISSN 2164-4063

2013, Vol. 3, No. 6

Cambridge University Press, New York, NY. Churchill, G.A. (1979), “A paradigm for developing better measures of marketing constructs", Journal of Marketing Research, Vol. 16 No. 1, pp. 64-73.

- Chebat, J.-C., Davidow, M. and Codjovi, I. (2005), "Silent voices: why some dissatisfied consumers fail to complain", Journal of Service Research, Vol. 7 No. 4, pp. 328-42.

- Day, R.L. and Landon, E.L. (1977), "Towards a theory of consumer complaining behaviour", in Woodside, A., Sheth, J. and Bennett, P. (Eds), Consumer and Industrial Buying Behaviour, North-Holland, Amsterdam.

- Goffman, E. (1967), Interaction Ritual: Essays in Face-to-Face Behavior, Aldine Publishing Company, Chicago,

- Harris, L.C. (2006) "Deviant customer behavior: an exploration of frontline employee tactics", Journal of Marketing Theory and Practice, Vol. 14, No. 2, pp. 95-111

- Hirschman, A. (1970), Exit, Voice, and Loyalty: Responses to Declines in Firms, Organizations, and States, Harvard University Press, Cambridge, MA. House,

- Hirschman, A.O. (1970), Exit, Voice, and Loyalty: Responses to Decline in Firms, Organizations, and States, Harvard University Press, Cambridge,

- Huang, J.H., Huang, C.T. and Wu, S. (1996), "National character and response to unsatisfactory hotel service", International Journal of Hospitality Management, Vol. 15 No. 3, pp. 229-43.

- Huppertz, J.W. (2007), 'Firms' complaint handling policies and consumer complaint voicing", The Journal of Consumer Marketing, Vol. 24 No. 7, pp. 428-37.

- J. (1989), 'Determinants of consumers' decisions to seek third party redress: an empirical study of dissatisfied patients", Journal of Consumer Affairs, Vol. 23 No. 2, pp. 329-63.

- Kim, C., Kim, S., Im, S. and Shin, C. (2003), "The effect of attitude and perception on consumer complaint intentions", Journal of Consumer Marketing, Vol. 20 Nos 4/5, pp. $352-71$

- Levesque, T.C. and McDougall, G.H.G. (2000), "Service problems and recovery strategies: an experiment", Canadian Journal of Administrative Sciences, Vol. 17 No. 1, pp. 20-37.

- Levesque, T.C. and McDougall, G.H.G. (2000), "Service problems and recovery strategies: an experiment", Canadian Journal of Administrative Sciences, Vol. 17 No. 1, pp. 20-37.

- Mittal, V., Huppertz, J.W. and Khare, A. (2008), "Customer complaining: the role of tie strength and information control”, Journal of Retailing, Vol. 84 No. 2, pp. 195-204. 


\section{Macrothink}

International Journal of Learning \& Development

ISSN 2164-4063

2013, Vol. 3, No. 6

- Naus, F., Iterson, A.V. and Roe, R. (2007), “Organizational cynicism: extending the exit, voice, loyalty and neglect model of employees' responses to adverse conditions in the workplace", Human Relations, Vol. 60 No. 5, pp. 683-99.

- Panther, T. and Farquhar, J.D. (2004), "Consumer responses to dissatisfaction with financial service provider: an exploration of why some stay while others switch", Journal of Financial Services Marketing, Vol. 8 No. 4, p. 343

- Phau, I. and Sari, R.P. (2004), "Engaging in complaint behaviour: an Indonesian perspective", Marketing Intelligence \& Planning, Vol. 22 No. 4, p. 407

- Phau, I. and Sari, R.P. (2004), "Enganging in complaint behavior", Marketing Intelligence \& Planning, Vol. 22 No. 4, pp. 407-26.

- PiotrChelminski, P. and Coulter, R.A. (2011), "An examination of consumer advocacy and complaining behavior in the context of service failure", The Journal of Services Marketing, Vol. 25 No. 5, pp. 361-70.

- Richins, M.L (1987) “A multivariate analysis of responses to dissatisfaction”, journal of academy of marketing science, Vol. 15, No. 3, pp. 24-31.

- Richins, M.L. (1987), "A multivariate analysis of responses to dissatisfaction", Journal of the Academy of Marketing Science, Vol. 15, Fall, pp. 24-31. Sheth,

- Richins, M.L. (1987), "A multivariate analysis of responses to dissatisfaction", Journal of the Academy of Marketing Science, Vol. 15 No. 3, pp. 24-31.

- Rizwan, M., Ali, S. H., Akhter, S., Abbas, Y., Kanwal, A., Iqbal, S. \& Aziz, W. (2013) Determinants Affecting Consumer Complaining Behavior: A study in a University of Pakistan, Asian Journal of Empirical Research, 3(2), 160-174

- Rizwan, M., Khan, A., Saeed, I., Shah, K., Azhar, N. \& Anam, W. (2013) Determinants of Customer Complaining Behavior, International Journal of Research in Computer Applications and Management, 3(3), 119-124

- Singh, J. (1988), “Consumer complaint intentions and behavior: definitional and taxonomical issues", Journal of Marketing, Vol. 52, January, pp. 93-107.

- Singh, J. (1988), "Consumer complaint intentions and behavior: definitional and taxonomical issues”, Journal of Marketing, Vol. 52 No. 1, pp. 93-107.

- Singh, J. (1990), “A typology of consumer dissatisfaction response styles (includes bibliography)", Journal of Retailing, Vol. 66 No. 1, p. 57.

- Singh, J. and Wilkes, R.E. (1996), "When consumers complain: a path analysis of the key antecedents of consumer complaint response estimates", Journal of the Academy of Marketing Science, Vol. 24 No. 4, pp. 350-65

- Tschlo, J. (1994), "Do yourself a favor: gripe about bad service", The American Salesman, Vol. 39, pp. 3-5. 
- Yuksel, A., Kilinc, U.K. and Yuksel, F. (2006), "Cross-national analysis of hotel customers' attitudes toward complaining and their complaining behaviours", Tourism Management, Vol. 27 No. 1, pp. 11-24.

- Yuksel, F. (2006), “Cross-national analysis of hotel customers' attitudes toward complaining and their complaining behaviours", Tourism Management, Vol. 27 No. 1, pp. 11-24. 